\title{
TRANSMISSION OF CHLORAMPHENICOL-RESISTANT SALMONELLA TYPHI IN MEXICO
}

\author{
ABEL GONZALEZ-CORTES \\ DAVID BESSUDO \\ RAFAEL SANCHEZ-LEYVA \\ RAFAEL FRAGOSO \\ MARINA HINOJOSA \\ POLA BECERRIL
}

Unit of Epidemiology and Enteric Diseases Laboratory, institute of Health and Tropical Diseases, Secretaria de Salubridad y Asistencia, and Zacatecas State Public Health Service, Mexico

\section{SUMMARY}

In mid 1972 an outbreak of typhoid due to a chloramfenicol resistant strain of Salmonella typhi occurred in a small village in central Mexico 83 cases were recorded, with 6 deaths. The highest attackrates were for the age-groups 1-14 and 45 and above. Most patients lived in an area of the village with the highest population density and the lowest income leve1s, close to an irrigation canal which traverses the village. Just before the epidemic the municipal water system had not been operational because of a defective pump. Food-specific attack-rates implicated the drinking of water from the canal as the source of the disease, and restoration of the water system just before the start of the investigation promptly halted the outbreak.

INTRODUCTION

IN early 1972 an epidemic of typhoid fever due to a chloramphenicol-resistant strain of Salmonella typhi began in central Mexico. At first an area including Mexico City and the States of Hidalgo and Mexico was involved, but the epidemic quickly spread to the adjacent States of Puebla and Tlaxcala, and in sub sequent months thousands of cases were reported. Epidemiological studies thus far have failed to reveal the source of the epidemic.1-3

Beginning in May, 1972, outbreaks of typhoid due to the chloramphenicol-resistant strain were recorded in communities outside of the Valley of Mexico. We describe here one such out break which occurred in 
the community of Ciudad Cuauhtémoc in the State of Zacatecas. In this instance, the source of the outbreak was related to the ingestion of contaminated water from an irrigation canal.

Ciudad Cuauhtémoc is a rural community of 3973 inhabitants about $90 \mathrm{~km}$. south of Zacatecas City The village is on a high plain with a temperate and dry climate. Most of the inhabitants work on nearby communal farms where the principal crops are com and beans. The land is not very fertile, and the income of the villagers is low.

The village has a municipal water system to which almost all of the houses are connected. The source of water for this network is a deep well $1 \mathrm{~km}$ east of the village. The water is neither filtered nor chlorinated. The village also has a sewage system to which les s than $15 \%$ of the houses are connected. Most of the population use outhouses or latrines or, quite commonly, defecate on the open soil.

The town is divided by a river which runs from west to east. This river is dry for most of the year; however, at several points the municipal sewage system discharges untreated waste directly into the river bed, producing stagnant pools. The community is al so bisected by a cement-lined irrigation canal which parallels the course of the river, branching once. This canal usually contains water, the source of which is a nearby dam and reservoir.

There is a single health centre which has a 4-bed infirmary staffed by a doctor and a licensed nurse. There are neither other doctors nor hospital facilities. Patients requiring hospital admission must travel north to Zacatecas or south to Aguasealientes.

As elsewhere in Mexico, enteric disease is hyper endemic in Ciudad Cuauhtémoc. Although typhoid fever has been recorded, it is not common. During 1971 no cases were reported from the community and only 41 cases from the entire 5 tate of Zacatecas (population 951,000). During the first 5 months of 1972, only 2 cases were reported in Ciudad Cuauhtémoc.

METHODS

All households in the community were contacted in a house-to-house survey. People with histories of recent illness were examined and questioned to determine if they had had typhoid fever. Criteria for the diagnosis of typhoid included sustained fever, gastrointestinal symptoms, prostration, hepatoesplenomegaly, and where possible isolation of S. typhi or significant rises in anti-O and anti-H titers.

A series of questionnaires were administered to people with typhoid and to healthy individuals selected at random from surrounding households. Samples of food and water were collected for bacteriological analysis and were 
83 cases of typhoid fever were identified in the Ciudad Cuauhtémoc outbreak. From them a total of 19 strains of $S$. typhi were isolated, 13 from heces and 6 from blood. 17 of the 19 strains were resistant to chloramphenicol and 2 were sensitive, as shown by the disc sensitivity test. 3 of the resistant strains and the 2 sensitive ones were phage typed. One of the sensitive strains was identified as phage type E1 and the other was a W form. The three resistant strains were classified as Vi degraded approaching phage type A, the characteristic strain found in most of the outbreaks in Mexico during 1972.5-7

In addition, $56 \%$, of the cases had Widal anti-O title of $1 / 160$ or greater by the plate method In the remaining cases in which there was neither bacteriological nor serological confirmation, the diagnosis was based on clinical grounds only.

Most patients (68\%) were between the ages of 1 and 14 years, but al! age-groups were affected (table r). Similarly, attack-rates were greater for the 1-4 and 5-15 age-groups, although rates were also raised for the groups 45 years of age and above. The attack rate was 1'74 per 100 and the ratio of affected males to females was 1/1'4 (table r).

The attack-rate was appreciably greater for females than for males $(2.3$ per 100 inhabitants $v$. 1.5 per 100 inhabitants). The difference was largely produced by disparities in the attack-rates for the two sexes in the 5-14 and 45 + age-groups, especially that of the 5-14 group in which the rates were 4.2 per 100

\begin{tabular}{|c|c|c|c|c|c|c|}
\hline ! & & ale & Female & & Tot: & \\
\hline Age (yr.) & No. Ht. & No. ill & No. Hts & No ill & No.hts. & No. ill \\
\hline $\begin{array}{r}-1 \\
1-4\end{array}$ & $\begin{array}{r}64 \\
288\end{array}$ & 1 & $\begin{array}{r}85 \\
252\end{array}$ & & 149 & 1 \\
\hline 5-14 & 665 & $11(1.65)$ & 638 & $27(4.23)$ & 1303 & $38(292)$ \\
\hline $15-24$ & 419 & $5(1.19)$ & 371 & $4(1.08)$ & 790 & 9 (1.14) \\
\hline $25-44$ & 354 & $3(0.85)$ & 348 & $2(0.57)$ & 702 & $5(0.71)$ \\
\hline$>45$ & 254 & $3(1.18)$ & 235 & $6(255)$ & 489 & $9(1.84)$ \\
\hline Total & 2044 & $31(1.52)$ & 1929 & $45(2.33)$ & 3973 & $76(1.91)$ \\
\hline
\end{tabular}

Figures in italic show rate per 100 inhabitants in each age-group. 


\begin{tabular}{|c|c|c|c|c|c|}
\hline \multirow{2}{*}{ Food (or drink) } & \multicolumn{2}{|c|}{ Ate } & \multicolumn{2}{|c|}{ Did not eat } & \multirow{2}{*}{$\begin{array}{l}\text { Differen- } \\
\text { tial rate } \\
\text { (f } 100)\end{array}$} \\
\hline & Total & III & Total & II & \\
\hline Water from the canal & 161 & $42(26-1)$ & 44 & $3(7)$ & $+19 \cdot 3^{\prime}$ \\
\hline Water from truck & 188 & $36(192)$ & 13 & $4(31)$ & $--11-6$ \\
\hline Well water & 74 & $14(19)$ & 47 & $6(13)$ & $! 6-2$ \\
\hline Milk & 114 & $26(228)$ & 185 & $44(23-8)$ & $\therefore \quad 1.0$ \\
\hline Fruit drink & 41 & $13(32)$ & 272 & $61(22 \cdot 4)$ & ! $9 \cdot 3$ \\
\hline Sliced fruit & 97 & $27(28)$ & 217 & $48(221)$ & 15.7 \\
\hline Vegetables & 115 & $17(14-8)$ & 196 & $56\left(28^{\prime} 6\right)$ & $-\mathrm{I} 3-8$ \\
\hline Meat & 176 & $32(182)$ & 136 & 40 (294) & $11-$ \\
\hline Popsicles (ice-cream) & 146 & $39(267)$ & 165 & 34 (206) & $f 6.1$ \\
\hline Cream & 15 & $2(13)$ & 308 & $71\left(23^{\prime} 1\right)$ & 97 \\
\hline Butter & 10 & $3(, 105)$ & 299 & $71\left(23{ }^{\prime} 8\right)$ & 63 \\
\hline Margarina & 6 & 0 & 306 & 73 (239) & 239 \\
\hline Tacos & 106 & $21(198)$ & 205 & $53(259)$ & $6 \cdot 0$ \\
\hline Sherbet & 93 & $15(16)$ & 207 & $55\left(26^{\prime} 6^{\prime}\right)$ & 104 \\
\hline Snowcones (ice) & 122 & $27\left(22^{\prime} 1\right)$ & 189 & $48(2,54)$ & 33 \\
\hline
\end{tabular}

inhabitants for females and 1-6 per 100 inhabitants for males,

Most patients lived in the north-east and east of the town, an area comprising approximately II third of the city, within which the attack-rate for inhabitants was 4-0 per 100 inhabitants as compared to 2-1 per 100 inhabitants for the entire town, Individual blocks had attack-rates which varied from 1 per 100 inhabitants to 16 ' 8 per 100 inhabitants. Of the 83 cases analyzed, 43 (52\%) were clusters with multiple cases per household, and 40 were isolated cases.

During the investigation we learned that because of a defective pump the entire population had been without municipal water throughout May and between June 10 and June 28. During these periods the people had used water from the canal without boiling it or had obtained supplies from trucks bringing water from distant wells.

The canal itself was subsequently studied, having been divided for the purposes of investigation into three segments during its course through the village. The first segment corresponded to that part of the canal most upstream, the second to the middle section of the canal, and the third segment to that part farthest downstream. The banks of the first segment had extensive accumulations of human feces, lesser degrees of accumulation were noted in the second, and still less in the third segment However, in the latter 
portion of the second serpent, several! Pipes were discovered to be discharging raw sewage into the canal from private multifamily systems.

Analysis of questionnaires completed for both ill and well inhabitants revealed a differential attack-rate of 26-1 per 100 for those drinking water from the canal as compared to 6-8 per 100 for those obtaining water from other sources (table n). In contrast, differential attack-rates for water from other sources and a variety of food and beverages were not significantly different for those who were or were not exposed to these items. Most cases lived in the section of the community adjacent to the third segment of the canal (the segment farthest downstream).

Of the bacteriological specimens collected, samples of pork, beef, cheese, and milk were a11 negative. An S. arizona species was isolated from a single specimen of chicharron (fried pig fat). Specimens of water from the canal a11 were heavily contaminated with coli forms; however, no attempts were made to isolate salmone11a from these specimens.

During the survey many of the people questioned reported gastrointestinal illness which roughly coincided with the period of the outbreak. Although no attempt was made to quantify the incidence of this illness, it was the impression of the investigators that there was a general increase in the incidence of gastrointestinal disturbances associated with the outbreak.

DISCUSSION

The Ciudad Cuauhtémoc typhoid out break is of interest as an instance of water-borne transmission of a chloramphenicol/resistant epidemic strain o S. typhi. We suggest that the water of the canal was contaminated by an individual (or individuals) infected with the resistant strain elsewhere in Mexico and that because of the lack of availability of municipal water the community was infected through the ingestion of canal water.

The high rates of attack in the inhabitants of the section of the village adjacent to the portion of the canal most downstream can be partly explained by greater likelihood of exposure. '1'his section is the most densely populated of the village, and the families with the lowest level of income and education live there. When the municipal water supply was interrupted, trucks brought water in. In the most crowded section, however, people had to wait for a 
long time to get water from the trucks and many decided to use water from the canal instead. The low general attack-rate was probably related to low concentrations of S. typhi in the canal water. The higher attack-rates in women may have be en related to greater likelihood of exposure because women were responsible for obtaining water for the family.

The high mortality-rate was probably related to the lack of medical care and the frequent use of chloramphenicol despite the known resistance of the organism to this agent. Unfortunately we do not know the specific treatment received by those who died.

The fact that all age-groups were affected and that the out break ended as soon as the water supply was reestablished supports the hypothesis of the canal water as the vehicle of infection. Unfortunately S. typhi was not isolated from the water nor was it possible to identify a person (or persons) who served as the source of contamination of the canal.

Although the epidemic was eased by a strain of S. typhi resistant to chloramphenicol, a small proportion of sensitive strains were al so found in outbreaks occurring in other parts of Mexico produced by this strain (Vi degraded approaching phage type A), approximately $10 \%$ of the isolates were sensitive to chloramphenicol, most of them belonging to phage types 26 and EJ. These sensitive strains were probably endemic in each community before the outbreaks.3, 8

We thank Dr Paul E. Pierce. and Dr Eugene J. Gangarosa, Center for Disease Control, Atlanta, Georgia, who made suggestions to improve the fieldwork and data interpretation; and Dr José Lopez Franchini, Zacatecas Sate Health Department, for this cooperation.

Requests for reprints should be addressed to A. G. C., Instituto de Salubridad y Enfermedades Tropicales, Carpio 470, México 17, México.

$$
\text { REFERENCES }
$$

1. González-Cortes, A., Heredia-Duarte, A., Guzmán Baena, J. Salud Púb. Méx. (in the press).

3. González/Cortes, A., Besudo, D., Velez V. Ibíd. 1972, 14, 697.

4. Besudo, D., Olarte Jorge, Mendoza Hernández P., Galindo, E" Carrillo, I., Gutiérrez-Trujillo, G., Kumate., J. Bol. ofna. Sanit. Panam. 1973, 74, 1.

5. Bernard, R. P.J.Hyg Camb. 1956, 63, 537

6. Varela, G., Mendoza-Hernández, P., Vázquez, A., Revta. IInst. Salubr.

Enferm. Trop. Méx. 1956, 18, 33 .

6. Gangarosa, J. B., Bennett, V. J., Wyatt, C., Pierce, P., Olarte, J, Mendoza-Hernández, P., Vázquez, V., Bezudo, M. D. J. infec. Dis. $1972,128,215$. 
7. Anderson, E. S., Smith, H. R. Br. Med. J. 1972, iii, 329.

8. Center for Disease Control Weekly Reports 1972. Morbidity and Mortality, pp. 21, 177, 193,213,239,290, and 327. 